\title{
Rozwiązania konstrukcyjne układów biegowych wagonów osobowych przystosowanych do wysokich prędkości
}

\begin{abstract}
$W$ artykule omówiono rozwiqzania konstrukcyjne układów biegowych przystosowanych do wysokich prędkości ze szczególnym uwzględnieniem poszczególnych podzespołów oraz części. Rozwiazania te odniesiono do wymagań, przedstawionych $w$ przepisach międzynarodowych. Artykut powstat w ramach projektu badawczo-rozwojowego Nr R10 041 02, finansowanego przez Ministerstwo Nauki i Szkolnictwa Wyższego ze środków budżetowych na naukę na lata 2007:2009 pt.,, Wózek pasażerskiego pojazdu kolejowego typu Z o prędkości $250 \mathrm{~km} / \mathrm{h}$ i możliwości modyfikacji do prędkości $300 \mathrm{~km} / \mathrm{h}$ ”.
\end{abstract}

\section{Wstęp}

Transport osobowy z wysokimi prędkościami ma już długoletnią tradycję. Związane jest to między innymi $\mathrm{z}$ wdrożeniem zespołów trakcyjnych typu „Shinkansen” w Japonii w 1964 roku, TGV we Francji w 1982 roku, ICE w Niemczech w 1992. Przydatność zespołów trakcyjnych przystosowanych do wysokich prędkości $\mathrm{w}$ transporcie osobowym została potwierdzona przez długoletnią eksploatację w Europie Zachodniej (SNCF, DBAG) oraz w Japonii ( JNR, JNR Central, JR West, Central+West) [1,2,3,6 i 7]. Ożywienie powstało również $\mathrm{w}$ transporcie realizowanym za pomocą wagonów osobowych ciągnionych $\mathrm{w}$ dowolnie formowanych składach przez lokomotywę, które w coraz większym stopniu są przystosowywane do wysokich prędkości i mogą skutecznie konkurować z zespołami trakcyjnymi [1]. $Z$ tego wynika potrzeba projektowania i wykonania układów biegowych przystosowanych do wysokich prędkości, powyżej 250 $\mathrm{km} / \mathrm{h}$ zgodnie z karta UIC 660 [30]. Jak pokazują współczesne doświadczenia i prace studialne ruch osobowy z wysokimi prędkościami można zrealizować przy wspólnym wysiłku konstruktorów pojazdu oraz infrastruktury, zwłaszcza w dziedzinie zapewnienia prawidłowych własności dynamicznych oraz ograniczenia emisji hałasu [8]. Konstrukcja układu biegowego musi spełniać wymagania odpowiednich przepisów oraz norm europejskich, opracowanych przez Europejski Komitet Normalizacyjny -CEN ( fr.,, Comité Européen de Normalisation" ), kart UIC, przepisów ORE/ERRI oraz RIC (wł. „Regolamento Internationale Carozza").

\section{Wymagania dla układów biegowych}

2.1.Przepisy międzynarodowe, jakie muszą spelniać uklady biegowe

Układ biegowy przystosowany do wysokich prędkości musi spełniać następujące przepisy:
* karty UIC 515-0 [16] w zakresie geometrii określonej przez tzw. „otoczkę wózka”(niem .,Kernhüllraum”, „Hüllraum”); przez „otoczkę wózka" rozumie się przestrzeń przeznaczoną dla wózka, włącznie z ugięciami pionowymi wynikającymi z obciążenia, zużycia i przemieszczeń $\mathrm{w}$ kierunku poziomym, wynikającym z luzu w kierunku poprzecznym w pierwszym i drugim stopniu usprężynowania (rys.1 i rys.2). „Otoczka wózka" jest przewidziana dla bazy wózka (odległości pomiędzy zestawami kołowymi) znajdującej się w zakresie $2,50 \div 2,60 \mathrm{~m}$.

* karty UIC 518 [22] i normy PN-EN 14363: 2005 [40] w zakresie własności bezpieczeństwa przed wykolejeniem w warunkach quasi-statycznych podczas przejazdu pojazdu przez tory wichrowate oraz własności dynamicznych i oddziaływania na tor w trakcie jazdy

* karty UIC 515-4 [19] i normy PN-EN 13749:2005 [39] w zakresie własności wytrzymałościowych ram (badania statyczne i zmęczeniowe);

* PN-EN 13260:2006 [35], PN-EN 13261:2004 [36], PN-EN13262:2005 [37] w zakresie warunków technicznych wykonania i odbioru, tolerancji kształtu i położenia zestawów kołowych, osi i kół

* PN-EN 13103: 2003 [34] w zakresie wytrzymałości statycznej i zmęczeniowej osi zestawu kołowego (metodyka obliczeń)

* karty UIC 505-1 [12] w zakresie spełnienia wymagań skrajni kinematycznej

* karty UIC 410 [11], 543 [24], 544-1 [25] i 546 [27] w zakresie wyposażenia hamulcowego

* karty UIC 515-1 [17] w zakresie warunków, jakie muszą spełniać dodatkowo podzespoły w stosunku do warunków ustalonych w kartach UIC 515-3 [18] oraz 515-5 [21] 

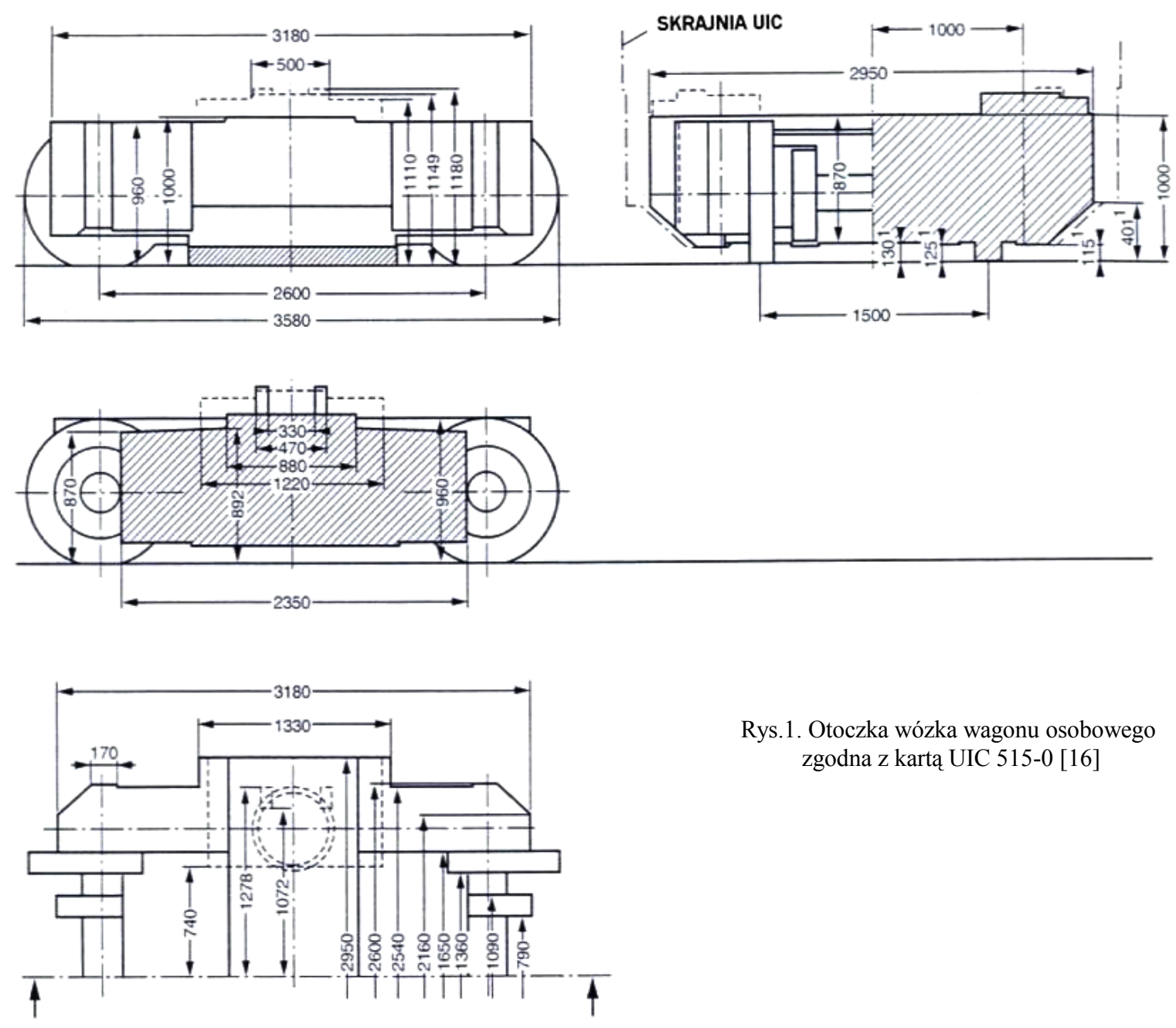

Rys.1. Otoczka wózka wagonu osobowego zgodna z kartą UIC 515-0 [16]

Rys.2. Otoczka wózka wagonu osobowego w ujęciu przestrzennym zgodnie $\mathrm{z}$ kartą UIC 515- 0 [16]

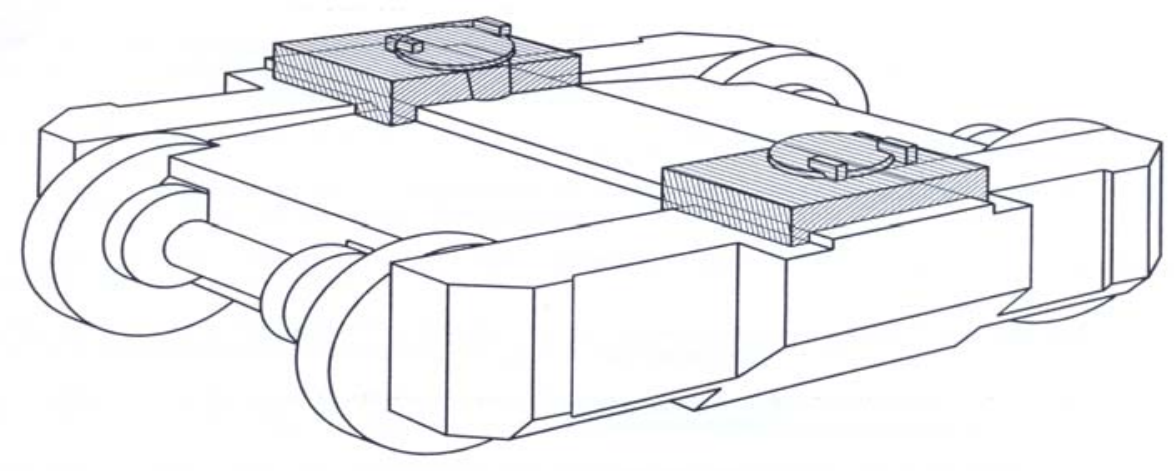

* karty UIC 515-5 [16] oraz PN-EN 12082:2000 [33] w zakresie maźnic

* karty UIC 533 [23] w zakresie wyposażenia w uziemienie ochronne przed porażeniem personelu obsługującego i podróżnych

* karty UIC 541-05 [26] w zakresie wyposażenia układu biegowego w urządzenie antypoślizgowe

* karty UIC 552 [28] w zakresie ochrony łożysk i smaru przed uszkodzeniami spowodowanymi przepływem prądów elektrycznych
* karty UIC 814 [31] w zakresie własności smaru zastosowanego w łożyskach tocznych maźnic

* karty UIC 822 [32] i PN-EN 13298:2003 [38] w zakresie produkcji, warunków technicznych wykonania i odbioru sprężyn śrubowych zastosowanych w zawieszeniu pierwszego i drugiego stopnia. 


\subsection{Badania potrzebne do udzielenia tymczasowe- go dopuszczenia}

W celu dopuszczenia wózka do eksploatacji komercyjnej musi on być poddany następującym badaniom:

$\Rightarrow$ badania stanowiskowe, aby wykazać wytrzymałość części konstrukcyjnych wózka tzn.: łożysk, maźnic, ramy wózka, sprężyn, tłumików, sytemu przegubów i elementów gumowo-metalowych

$\Rightarrow$ badania podczas jazdy, aby dostarczyć dowód poprawnych własności dynamicznych dotyczących bezpieczeństwa jazdy, komfortu i obciążenia toru.

Wagon przystosowany do wysokich prędkości musi posiadać tak zaprojektowane układy biegowe, aby mógł przejść dodatkowe próby i badania:

$\Rightarrow$ wagon musi posiadać możliwość przejazdu przez łuki toru o promieniu $\mathrm{R}=150 \mathrm{~m}$, jeśli wagony znajdują się w składzie pociągu

$\Rightarrow$ pojedynczy wagon $\mathrm{z}$ układami biegowymi musi przejeżdżać w stanie próżnym przez warsztatowe luki toru o promieniu $80 \mathrm{~m}$

$\Rightarrow$ wagon musi przejeżdżać podczas wjazdu na prom łuk toru o promieniu $300 \mathrm{~m}$ i kącie pochylenia rampy promowej wynoszącego $2,5^{\circ}$, zgodnie $\mathrm{z}$ kartą UIC 507 [13].

Dodatkowe badania powinny być przeprowadzone albo przesuwnicy (badania stanowiskowe) albo na torze spełniającym powyższe kryteria. $\mathrm{W}$ trakcie ww. prób przejezdności żadna cześć wagonu nie może być uszkodzona oraz nie może wystapić kolizja pomiędzy częściami pudła wagonu oraz wózków.

\subsection{Dodatkowe wymagania wynikające $z$ trendów rozwojowych}

Poważnym wyzwaniem dla konstruktorów układów biegowych przystosowanych do wysokich prędkości jest między innymi masa własna. Porównanie poszczególnych mas własnych wózków wagonów osobowych przedstawiono na w tabeli 1 .
Wózek typu „Sumitomo” posiada wewnętrzne ułożyskowanie, dzięki czemu udało się ograniczyć masę własną całego układu biegowego jak również mas nieusprężynowanych. Rozwiązanie to nie spełnia wymagań karty UIC 515-1 [17] w zakresie współpracy z urządzeniami typu HOA do wykrywania przegrzanych łożysk tocznych umieszczonych $\mathrm{w}$ maźnicach. Urządzenia te są usytuowane na zewnątrz toru. Jednak karta UIC 660 [30] dopuszcza już zainstalowanie czujnika do kontroli temperatury łożysk na pojeździe, który musi funkcjonować tak, że przy wykryciu wzrostu temperatury następuje ograniczenie prędkości poruszającego się pojazdu względnie jego stopniowe zahamowanie aż do stopniowego zatrzymania się pociagu $\mathrm{w}$ zależności od zgłoszenia informacyjnego i ostrzegawczego. Zmniejszenie masy układu biegowego (zwłaszcza w zakresie mas nieusprężynowanych) można osiagnać przez wykorzystanie zapisu w karcie UIC 515-1 [17] w p.1.3.1 dotyczącego dopuszczalnych średnic tocznych kół w stanie nowym w zakresie $800 \div 1000 \mathrm{~mm}$, przy zalecanych wartościach w zakresie $890 \div 920 \mathrm{~mm}$. Karta UIC 515-1 [17] przedstawia w załączniku B dwa rozwiązania kół o średnicy w stanie nowym/ zużytym odpowiednio $\$ 920 / 870 \mathrm{~mm}$ i $890 / 840 \mathrm{~mm} \mathrm{z}$ dopuszczalnym zużyciem granicznym $31 \mathrm{~mm}$ na promieniu ( wynikającym z $25 \mathrm{~mm}$ do ostatniej reprofilacji (odtworzenia zarysu zewnętrznego wieńca koła oraz długości „rowka zużyciowego” wynoszącej $6 \mathrm{~mm}$ ) i masami wynoszącymi odpowiednio $320 \mathrm{~kg}$ oraz $307 \mathrm{~kg}$. Ww. wymagane i zalecane wartości średnic tocznych kół dla układów biegowych przystosowanych do wysokich prędkości są zgodne z przepisami karty UIC 510-2 [15]. Utrzymanie zarysu skrajni kinematycznej wg karty UIC 505$1[12]$ przy wyborze mniejszych średnic zestawów kołowych poniżej $920 \mathrm{~mm}$, wiąże się z poszukiwaniem tarcz hamulcowych o mniejszych średnicach, co z kolei przyczynia się do wzrostu temperatury pary ciernej okładzina hamulcowa-tarcza hamulcowa. Dlatego w przypadku wózka tocznego typu MD 530 przeznaczonego do zespołu trakcyjnego ICE zastosowano 4 tarcze hamulcowe zamontowane na jednej osi o
Zestawienie mas własnych ukladów biegowych zastosowanych w wagonach osobowych i zespołach trakcyjnych przeznaczonych do wysokich prędkości

Tabela 1

\begin{tabular}{|c|c|c|c|c|}
\hline L.p. & $\begin{array}{c}\text { Oznaczenie } \\
\text { wózka }\end{array}$ & $\begin{array}{c}\text { Prędkość mak- } \\
\text { symalna }[\mathrm{km} / \mathrm{h}]\end{array}$ & $\begin{array}{c}\text { Masa } \\
\text { własna } \\
{[\mathrm{t}]}\end{array}$ & Uwagi \\
\hline 1. & GP 210 & 250 & 6,8 & \\
\hline 2. & MD 530 & 280 & 7,52 & $\begin{array}{c}\text { z hamulcem } \\
\text { ręcznym }\end{array}$ \\
\cline { 3 - 5 } & SGP 400 & 300 & 7,42 & $\begin{array}{c}\text { bez hamulca } \\
\text { ręcznego }\end{array}$ \\
\hline 3. & SGe & 6,8 & \\
\hline 4. & "Sumitomo" & 350 & 5,5 & \\
\hline 5. & TR 400 & 350 & 4,9 & \\
\hline
\end{tabular}

wymiarach $640 \times 80 \mathrm{~mm}$, przy średnicy tocznej koła w stanie nowym, wynoszącej $\phi 920 \mathrm{~mm}$. W tym przypadku jednak założono, że zespół trakcyjny nie będzie przejeżdżał przez górki rozrządowe i hamulce torowe $\mathrm{w}$ położeniu pracy i jest utrzymany zarys odniesienia skrajni kinematycznej wg p.5.2 karty UIC 505-1 [12] ( rys.3). 


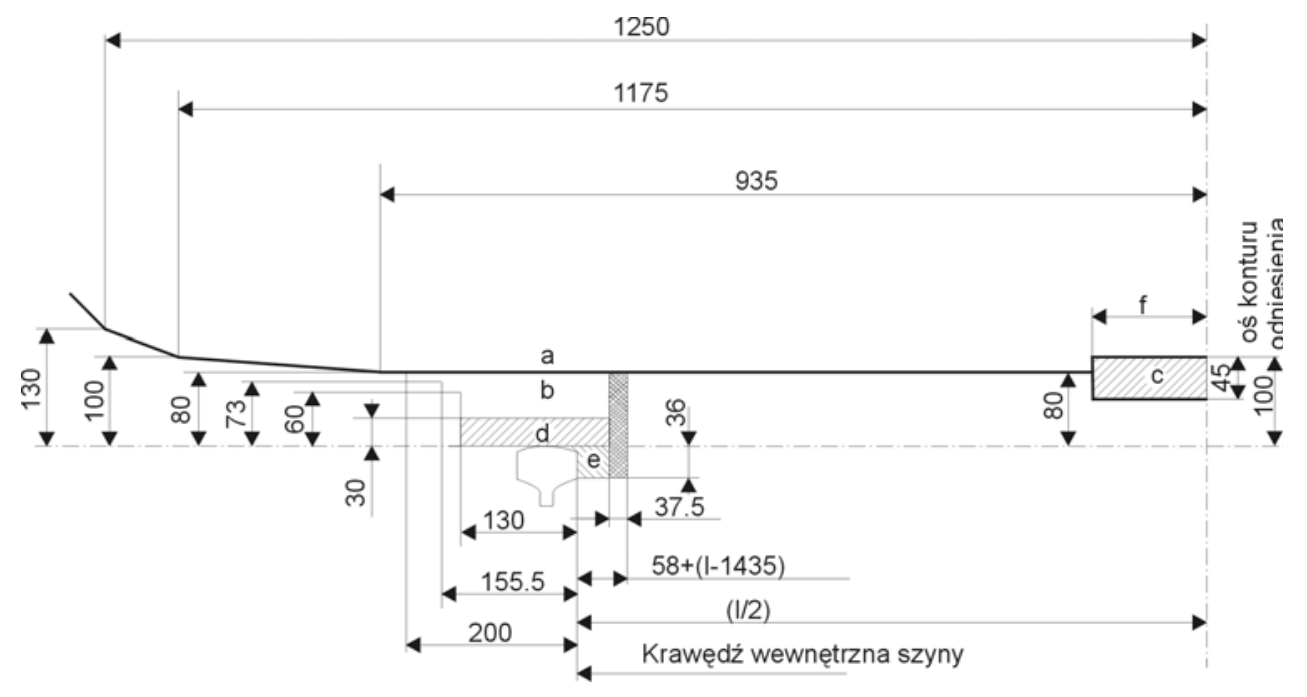

Rys.3. Zarys skrajni kinematycznej wagonów towarowych nie mogących przejeżdżać przez górki rozrządowe ani też nie mogących być hamowanymi za pomocą hamulców torowych wg p.5.2 karty UIC 505-1 [12]

\begin{abstract}
Legenda:
a-przestrzeń dla części konstrukcyjnych znajdujacych się w większej odległości od kót

b- przestrzeń dla części konstrukcyjnych w bezpośrednim sqsiedztwie kót

c-przestrzeń dla szczotek krokodyli ( automatycznych wytaczników blokad torowych-ang. „contact ramp”, niem.,,Krokodilen”), które sq stosowane przez niektóre zarzqdy kolejowe jak SNCF (wysokość od główki szyny $94 \mathrm{~mm}$ ) oraz SNCB (wysokość od główki szyny $96 \mathrm{~mm}$ )

d-przestrzeń dla kót i innych części, które stykaja się z szynami

e-przestrzeń przeznaczona wytacznie dla kót

(1) zarys odniesienia dla części konstrukcyjnych znajdujacych się za zewnqtrz skrajnych zestawów kołowych ( urzqdzenia czyszczace szyny, piaskujace), które zapewniaja przejazd przez petardy ochronne (ang. ,, detonators”, niem. , Knallkapseln”) Zarys odniesienia nie musi być zachowany dla części, które znajdujq się między kołami pod warunkiem, że znajduja się w tle kót

(2) największa dopuszczalna szerokość obrzeży kół przy występowaniu kierownic (ang. „,check-rail”, niem.,, Radlenker”)

(3) rzeczywiste położenie graniczne zewnętrznej powierzchni kót i części konstrukcyjnych, które sq połqczone z kołami. Dolne części konstrukcyjne sq zdefiniowane w karcie UIC 505-5 [30]

(4) jeśli pojazd znajduje się $w$ dowolnym ustawieniu $w$ tuku toru o promieniu $R=250 \mathrm{~m}$ (najmniejszy promień dla zainstalowania krokodyli) i o prześwicie toru $1465 \mathrm{~mm}$, wówczas żadna część pojazdu za wyjatkiem szczotki krokodyli (ang.,, contact ramp brushes”, ,niem. Krokodilenbürste” lub „,Kontaktbürste”) nie może przekroczyć wymiaru wynoszqcego 100 mm mierzonego względem główki szyny i nie może w znajdować się w odległości większej niż $125 \mathrm{~mm}$ od osi toru.

(5) rzeczywiste położenie graniczne wewnętrznej powierzchni czołowej kól, kiedy zestaw kołowy

(6) $1 / 2$ - połowa prześwitu toru (szerokości toru)
\end{abstract}

Problem utrzymania zarysu odniesienia skrajni kinematycznej wiąże się $\mathrm{z}$ doborem usprężynowania pierwszego i drugiego stopnia. Nie mniej jednak w wózku typu „S Sumitomo” zastosowano koła o średnicy tocznej będaccej w zakresie eksploatacyjnym $840 \div 780$ $\mathrm{mm}$, natomiast w wózku TR 400 firmy Bombardier $780 \div 730 \mathrm{~mm}$, przy czym obydwa przypadki wykraczają poza wymagany i zalecany przez kartę UIC 5151 [17] zakres eksploatacyjny średnicy tocznej. Rozwiązanie to przy tym samym nacisku zestawu kołowego jest bardziej narażone na zużycie koła, z tytułu większych nacisków powierzchniowych na powierzchni tocznej koła oraz większej prędkości obrotowej przy tej samej prędkości liniowej pojazdu. Istotnymi warunkami ograniczającymi są przede wszystkim przepisy karty UIC 515-1 [17] w p.2.1.5, gdzie ogranicza się wartość współczynnika pochylania pojazdu w stanie próżnym oraz we wszystkich stanach załadowania do 0,4 oraz w p.2.1.8, gdzie ogranicza się różnicę wysokości w stanie próżnym pudła wagonu odpowiadającemu przepisom RIC oraz karcie UIC 567-1[29] z kołami w stanie nowym oraz wagonu $\mathrm{z}$ kołami w stanie ładownym przy całkowicie zużytych zestawach kołowych przy obciążeniu normalnym do $80 \mathrm{~mm}$. Warunek przedstawiony w p.2.1.8 karty UIC 515-1 [17] jest ograniczeniem sumy zużycia oraz przyrostu ugięcia usprężynowania I i II stopnia próżny-ładowny. Jednocześnie prawidłowy dobór usprężynowania gwarantuje własności dynamiczne i komfort jazdy wymagany przez przepisy karty UIC 518 [22] oraz PN-EN 14363:2005 [40], co wymaga kompromisu w świetle ww. wymagań postawionych przez kartę UIC 515-1 [17]. Zgodnie z p.2.1.7 karty UIC 515-1[17] usprężynowanie wózka musi być tak zaprojektowane, aby posiadało „zdolności filtrujące” polegające na unikaniu propagacji emisji hałasu, powstającego w układzie koło-szyna. Zgodnie z p. 2.1.8 karty UIC 515-1 [17] usprężynowanie wózka powinno gwarantować możliwie duże przesuwy poprzeczne przy zachowaniu zarysu odniesienia 
skrajni kinematycznej. Jak wykazują doświadczenia uzyskane $\mathrm{z}$ badań zbyt sztywne usprężynowanie i małe przemieszczenia $\mathrm{w}$ kierunku poprzecznym powodują duże sprzężenie pomiędzy pudłem wagonu poprzez ramę wózka $\mathrm{z}$ torem, co wywołuje działanie dużych sił dynamicznych. To obowiązuje przed wszystkim podczas jazdy w łukach [5]. W związku z tym należy przewidzieć raczej duże przemieszczenia poprzeczne, co udowadnia przykład zespołu trakcyjnego X 2000 kolei szwedzkich lub zastosowanie tzw. aktywnych usprężynowań w kierunku poprzecznym tzw. AQS ( niem. „, aktive Querfedurungen”). System ten kompensuje w sposób częściowy lub pełny przemieszczenia poprzeczne pod wpływem siły odśrodkowej, co powoduje że pojazd dysponuje większymi przemieszczeniami poprzecznymi wynikającymi z błędów toru i zapewnia wymagany komfort dla podróżnych. Skutecznym rozwiązaniem, przynoszącym efekty jest zapewnienie maksymalnego luzu poprzecznego na torze prostym, wynoszącym $\pm 60 \mathrm{~mm}$ oraz $50 \mathrm{~mm}$ na zewnątrz łuku i $20 \mathrm{~mm}$ do wewnątrz łuku o promieniu $250 \mathrm{~m}$. Rozwiązanie to zostało zastosowane w wózku tocznym MD 530 i zapewnia jednoczesne spełnienie własności dynamicznych w kierunku poprzecznym jak również zarysu odniesienia skrajni kinematycznej zgodnie z raportem ORE/ERRI B176/DT278 [41].
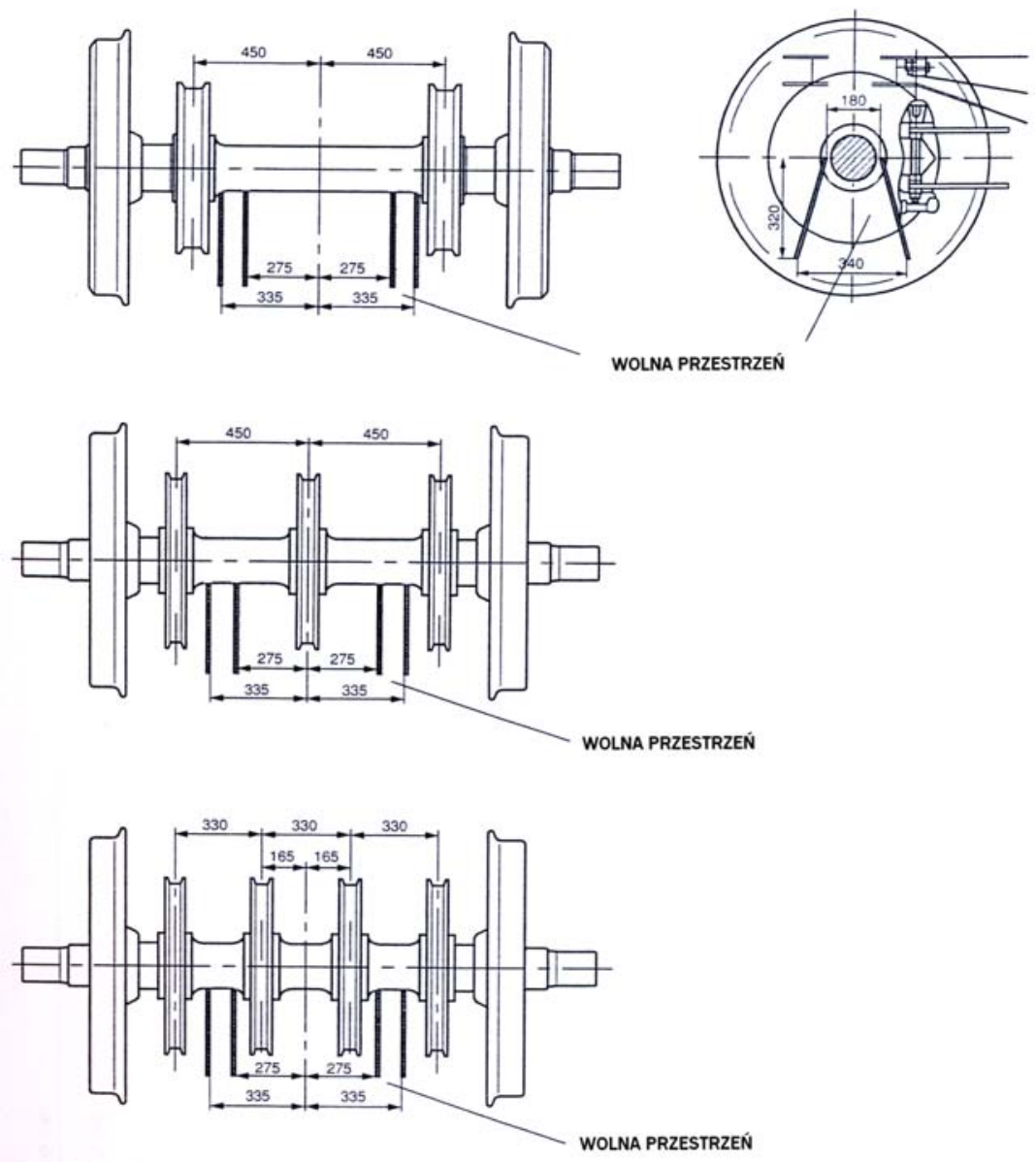

Rys.4. Wolna przestrzeń, którą należy zachować dla funkcjonowania urządzeń do podnoszenia zestawów kołowych, przy wykonywaniu prac konserwacyjnych i naprawczych zgodnie z kartą UIC 515-1 [17] oraz kartą UIC 508-2 [14]
Kolejnym zagadnieniem związanym z zapewnieniem prawidłowych własności dynamicznych jest luz wzdłużny $\mathrm{w}$ łożyskach tocznych. Jak wynika $\mathrm{z}$ doświadczeń uzyskanych podczas badań dynamicznych przeprowadzonych $\mathrm{w}$ zespole trakcyjnym "Shinkansen" luz ten powinien być ograniczony do $0,6 \mathrm{~mm}$. Powyżej tej wartości odnotowuje się negatywne oddziaływanie wężykowania zestawu kołowego na komfort jazdy. Jednocześnie badania potwierdziły bardzo dużą przydatność łożysk stożkowych. Zgodnie z p.2.1.6 karty UIC 515-1 [17] oraz p.5.3 karty UIC 660 [30] wózki eksploatowane z prędkością powyżej 200 $\mathrm{km} / \mathrm{h}$ muszą być wyposażone w czujnik do badania przyspieszeń, umieszczony na ramie w celu wykrycia niestabilności ruchu wózków; meldunek o zarejestrowanej niestabilności powinien być przekazany do kabiny maszynisty i wywoływać bezpośrednie działanie na układ hamulcowy pociagu. Rejestracja niestabilności dynamicznej musi odbywać się przez pomiar przyspieszenia w kierunku poprzecznym $y_{*_{S}}^{+}$na ramie wózka poprzez zestaw kołowy, przy czym wartość efektywna przyspieszenia nie może przekroczyć wartości granicznej (sÿ) $)_{\text {lim }}{ }^{+}$:

Nowoczesne układy biegowe muszą być zabezpieczone przed działaniem czynników atmosferycznych takich jak powietrze, deszcz, śnieg, pył i substancje chemiczne używane do mycia pojazdów szynowych. Czynnik ten jest bardzo istotny, gdyż jak wynika $\mathrm{z}$ badań przeprowadzonych przez Urząd Badań Ochrony Środowiska w Niemczech (niem. „Umweltbundesamt") około 300000 ton cząstek związków organicznych rocznie jest emitowanych do atmosfery [4]. W związku z tym układ biegowy oraz jego części (zwłaszcza zużywające się) nie mogą być źródłem emisji substancji szkodliwych dla środowiska naturalnego. Ma to odzwierciedlenie w p.7.2.1 karty UIC 515-1 [17], aby ilość części zużywających się ograniczyć do niezbędnego minimum. Oprócz tego do ochrony środowiska naturalnego przyczynia się zastosowanie farb i lakierów wolnych od zawartości metali ciężkich, ołowiu i chromu, które jednocześnie przyczyniają się do zabezpieczenia wytrzymałości zmęczeniowej elementów nośnych podczas eksploatacji. Przykład wpływu zabezpieczenia antykorozyjnego na wytrzymałość zmęczeniową udowodniły badania stanowiskowe przeprowadzone na partii sprężyn 
śrubowych. Wykazały one jednocześnie przydatność nowoczesnych farb i lakierów nawierzchniowych wodorozcieńczalnych, przyjaznych jednocześnie dla środowiska naturalnego [4].

Układ biegowy musi być dostosowany do bezpiecznej i niezawodnej eksploatacji $\mathrm{w}$ zakresie temperatur $25^{\circ} \div 40^{\circ} \mathrm{C}$.

Bardzo istotnym czynnikiem jest również problem ograniczenia emisji hałasu przez układ biegowy [8]. Przykładem takiej konstrukcji jest wózek toczny typu MD 530, gdzie zastosowano między innymi zestawy kołowe $\mathrm{z}$ kołami wyposażonymi $\mathrm{w}$ thumiki hałasu (zainstalowane od wewnętrznej strony tarczy kół), elementy gumowe $\mathrm{w}$ rejonie maźnic, elementy gumowo-metalowe sprężyn zawieszenia drugiego stopnia, zabudowane pomiędzy powierzchniami czołowymi sprężyn i oparcia na ramie, w ułożyskowaniu wahaczy oraz tuleję gumowo-metalową w czopie skrętu. Ww. zabiegi konstrukcyjne zmniejszaja przede wszystkim emisję hałasu układu biegowego powstającego w układzie koło-szyna (niem. „Rollgeräusch”). Poważny sukces w emisji hałasu zanotowano w zespołach trakcyjnych, w których zastosowano układ biegowy typu „Kawasaki” i aktywny system sterowania przechyłem pudła (ang.,,active suspension system"). Podczas jazd próbnych przy prędkości $300 \mathrm{~km} / \mathrm{h}$ otrzymano następujące wartości natężenia hałasu: $81,1 \mathrm{~dB}$ przy wyłączonym oraz $71,1 \mathrm{~dB}$ przy włączonym systemie sterowania przechyłem pudła.

Kolejnym problemem, który pojawia się przy zapewnieniu własności dynamicznych wagonu jest zaprojektownie odpowiednio sztywnej konstrukcji pudła, aby uniknąc jego drgań giętych oraz giętno-skrętnych $\mathrm{w}$ trakcie eksploatacji. Żródłem tych drgań są wymuszenia, powodujące drgania nadwozia wywołane przez nierówności geometryczne toru i kół oraz sinusoidalny bieg zestawów kołowych w torze (wężykowanie obrotowe i poprzeczne). Wymuszenia te są przenoszone przez strukturę pojazdu i wzbudzają drgania nadwozia w postaci: podskakiwania, galopowania, kołysania, wężykowania poprzecznego i wężykowania obrotowego. Drgania tego rodzaju wywołują z kolei drgania strukturalne pudła stalowego, przybierające liczne formy wyrażające się odkształceniami giętymi w kierunku poprzecznym i pionowym o charakterze postaciowym jego przekroju poprzecznego. Niniejsze zagadnienie polega na takim ukształtowaniu konstrukcji stalowej pudła, aby zapobiec jego „, rombowaniu” pod wpływem drgań strukturalnych $[8 \div 10]$.

Nowoczesne układy biegowe muszą spełniać również wymagania w zakresie części zużywających się i tak:

> wszystkie części zużywające się, które posiadają wpływ na bezpieczeństwo eksploatacyjne i jazdy muszą być poddane kontroli (między innymi wizualnej), która nie powinna być utrudniona

$>$ wszystkie części zużywające się muszą być łatwe do wymiany; zamocowanie ich musi być łatwo dostępne przy montażu i demontażu.

W przypadku tłumików drgań pionowych wężykowania musi być możliwość demontażu bez użycia kanałów, natomiast tłumiki drgań poziomych muszą dać się wymieniać z użyciem kanału przez personel obsługujący w sposób łatwy i nie sprawiający trudności.

\section{Przykłady nowoczesnych konstrukcji układów biegowych przystosowanych do wysokich pręd- kości}

Przykładem nowoczesnego układu biegowego jest wózek GP 210 przeznaczony dla wagonów osobowych, zaprojektowany i wyprodukowany przez firmę TransTec Vetschau GmbH ( rys.5.).

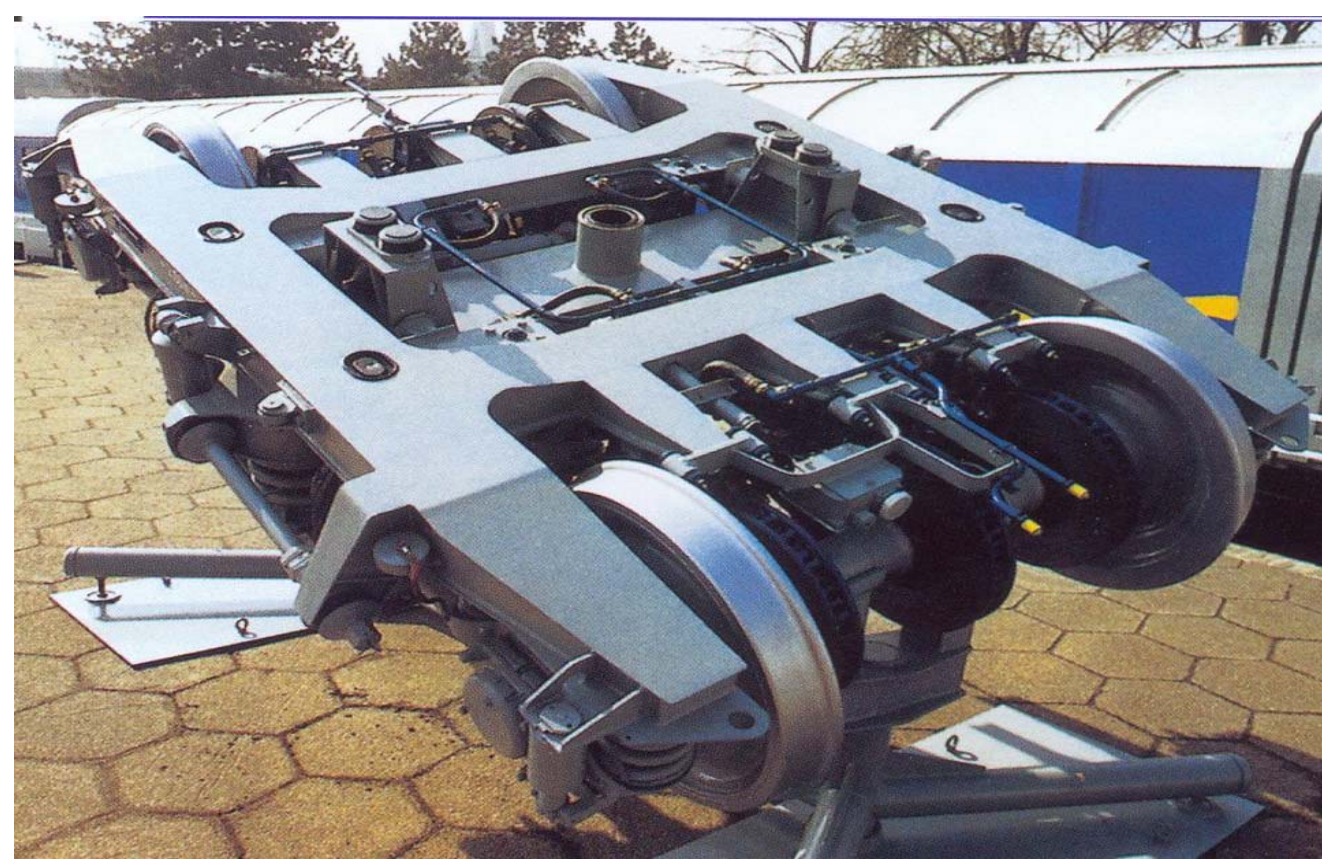

Rys.5. Wózek typu GP 210 wagonów osobowych, przystosowany do wagonów osobowych dla wysokich prędkości produkcji TransTec Vetschau GmbH wg [44] 
Zasadnicze parametry układu biegowego:

$>$ prześwit toru: $1435 \mathrm{~mm}$, możliwość modyfikacji na tor szeroki o prześwicie: $1520 \mathrm{~mm}$

$>$ hamulec tarczowy (3 tarcze hamulcowe przypadające na zestaw kołowy, hamulec szynowy elektromagnetyczny)

> prędkość: $250 \mathrm{~km} / \mathrm{h}$ (pod względem spełnienia wymaganych własności dynamicznych) i 200 $\mathrm{km} / \mathrm{h}$ (pod względem wymaganej intensywności hamowania)

$>$ materiał użyty na podstawowe elementy nośne ramy: TSt E355 ( St 52-3)

$>$ masa własna: $6,8 \mathrm{t}$

$>$ prowadzenie zestawu kołowego i belki bujakowej: za pomocą wahaczy odpornych na zużycie

$>$ połączenie układu biegowego z pudłem wagonu: poprzez czop skrętu

$>$ możliwość dopasowania do obciążeń pionowych na czop skrętu wynoszących 20,5 t, 23,5 t 25 t, $28 \mathrm{t}$

$>$ usprężynowanie pierwszego i drugiego stopnia: sprężyny śrubowe.
Kolejnym przykładem nowoczesnych konstrukcji układów biegowych jest wózek typu „Kawasaki” zaprojektowany przez japońską firmę Kawasaki Heavy Industries LTD w Tokio (rys.6). Na uwagę zasługuje zastosowanie aktywnego sterowania przechyłem pudła za pomoca silnika o charakterystyce liniowej, które zwiększa komfort podróżnych. Usprężynowanie pierwszego stopnia stanowią sprężyny śrubowe, natomiast drugiego stopnia stanowią sprężyny pneumatyczne.

$\mathrm{Na}$ rys.7 przedstawiono nowoczesne rozwiązanie układu biegowego typu Flexx Tronic Technology, który został zaprojektowany i wyprodukowany przez firmę Bombardier oraz jest wyposażony w system mechatroniczny pozwalający na aktywne sterowanie radialnym ustawieniem zestawów kołowych i aktywne sterowanie przechyłem pudła monitorujący geometrię toru i wózka podczas jazdy.
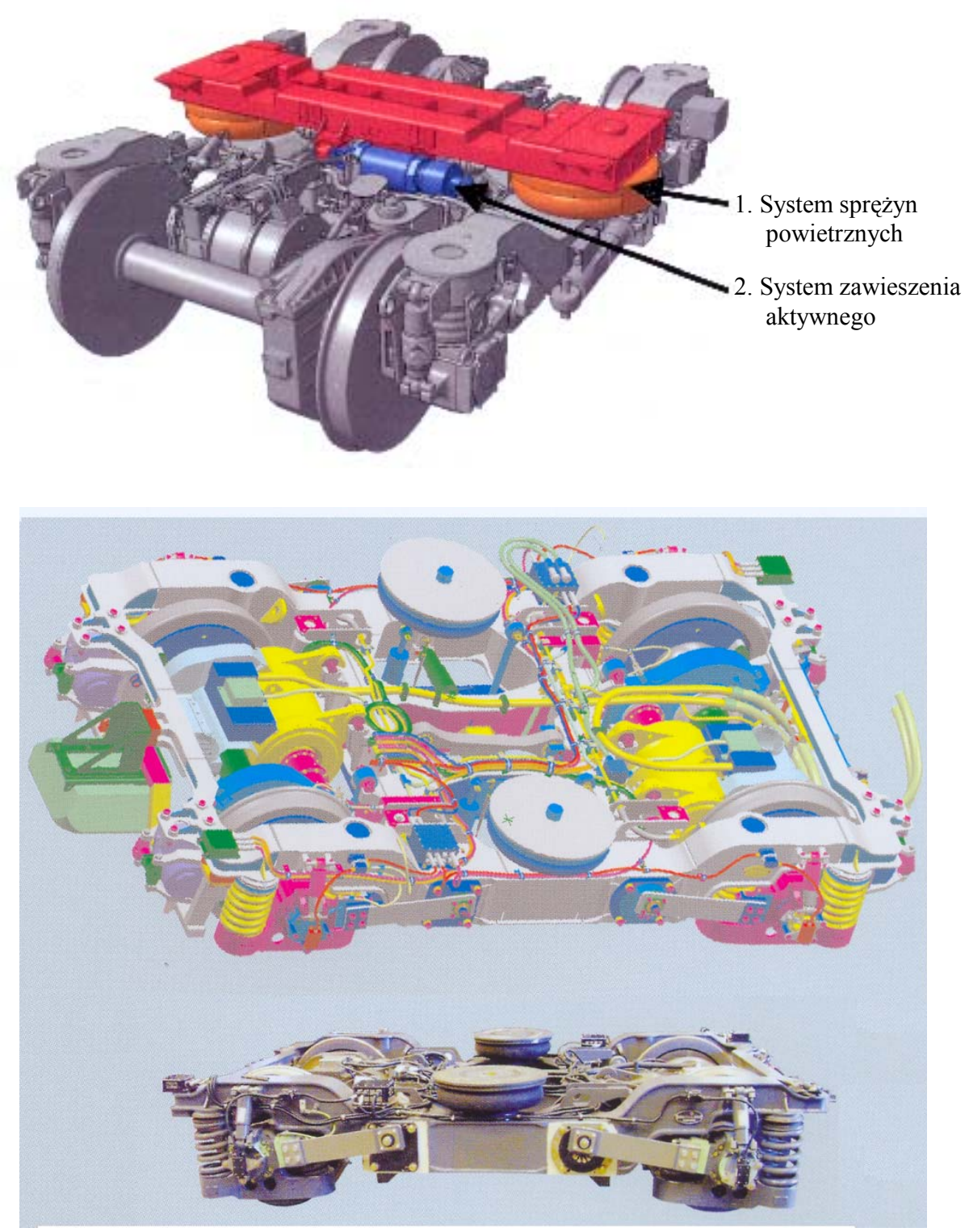

Rys.6. Wózek typu „Kawasaki” z aktywnym sterowaniem przechyłu pudła dla wagonów osobowych oraz zespołów trakcyjnych dla wysokich prędkości produkcji Kawasaki Heavy Industries Ltd wg [42]
Rys.7. Wózek typu Flexx Tronic Technology (Mechatronic Technology) przeznaczony do wagonów osobowych dla wysokich prędkości produkcji Bombardier Transportation wg [43] 


\section{Wnioski}

Skonstruowanie nowego układu biegowego dla wagonów osobowych przystosowanych do wysokich prędkości powinno bazować na wytycznych karty UIC 515-1[17]. Przestrzeganie „otoczki” wymaganej w karcie UIC 515-0 [16] wydaje się być celowe $\mathrm{z}$ punktu przyszłych modernizacji konstrukcji pudeł wagonów osobowych dostosowanych do prędkości $\mathrm{v} \leq 200 \mathrm{~km} / \mathrm{h}$. Przestrzeganie tych przepisów jest tylko wtedy uzasadnione o ile, nie uniemożliwia spełnienia innych wymagań, zwłaszcza dotyczących własności dynamicznych oraz hamulcowych, wynikających ze wzrostu prędkości z $200 \mathrm{~km} / \mathrm{h}$ do zakresu $250 \div 300$ $\mathrm{km} / \mathrm{h}$. Wymiary tarcz hamulcowych $\mathrm{w}$ kierunku pionowym mogą przyjmować większe wartości ze względów ograniczenia temperatury współpracujących par ciernych tarcze hamulcowe-okładziny cierne. Bardzo istotne jest również spełnienie wymagań skrajni kinematycznej wg karty UIC 505-1 [12]. Szczególną uwage przy konstruowaniu nowych układów biegowych należy zwrócić oprócz zagadnień dynamicznych (komfort jazdy), bezpieczeństwa jazdy ( przejazd przez tory wichrowate $\mathrm{w}$ warunkach quasistatycznych oraz oddziaływanie na tor) oraz hamulcowych (zapewnienie wymaganej hamowności, mierzonej przez drogę hamowania) na elementy związane $\mathrm{z}$ ochroną środowiska naturalnego, do jakich należą ograniczenie emisji substancji szkodliwych do otoczenia oraz emisji hałasu. Zainstalowanie tylko i wyłącznie hamulca tarczowego i rezygnacja $\mathrm{z}$ hamulca tarczowego nie jest gwarantuje jeszcze istotnego postępu w zwalczaniu hałasu. Kolejnym zagadnieniem, na jakie należy zwrócić uwage jest bezobsługowość poszczególnych elementów układu biegowego oraz ich łatwa dostępność podczas ewentualnych napraw, co rzutuje na ich koszty oraz utrzymania pojazdu w stanie gotowości do eksploatacji, czyli tzw. dyspozycyjność. Wiąże się to z ograniczeniem węzłów wymagających konserwacji i napraw jak np. węzeł łożyskowy, który tradycyjnie podlegał większemu nakładowi pracy ze względu na wymianę smaru. Istotnym czynnikiem przy projektowaniu jest zapewnienie bardzo dużej odporności poszczególnych części układu biegowego przed korozja, która zmniejsza wytrzymałość zmęczeniową. Dobór farb gruntowych i nawierzchniowych musi być również determinowany przez własności tłumiące drgań materiałowych oraz brak substancji szkodliwych dla środowiska naturalnego. Konstrukcja układu biegowego dla wagonów osobowych przystosowanych do wysokich prędkości jest poważnym wyzwaniem techno-

\section{Literatura}

[1] Adam H.D., Simbürger A., Oreski W.: Viaggio Comfort-Intercity-Reisezugwagen für das 21 Jahrhundert. Eisenbahntechnische Rundschau. Mai 2008. Nr. 04

[2] Bonnepart R., Raison J.: Die NeigetechnikErprobungsträger der SNCF-TGV mit Neigetechnik, Axis und Triebzug X-TER. Zevrail Glasers Annalen. 126 Tagungsband SFT Graz 2002.

[3] Jänsch E.: Fahrzeugentwicklungen für den Hochgeschwindigkeitsverkehr. Eisenbahningenieur 9.2001.

[4] Kaiser B.: Untersuchung des Korrosionsschutzes an Schraubenfedern für Schienenfahrzeuge. Eisenbahntechnische Rundschau Nr.132, 7+8. 2008.

[5] Madeyski T.: Fahrwerkstechnik. Zusammenwirken mit dem Fahrweg und dem Fahrzugkasten. Eisenbahntechnische Rundschau. Nr.48, 9.1999.

[6] Okamoto I.: Geschwindigkeitssteigerung des Shinkansen. Technologische Entwicklungen. Schienen der Welt. 08-09.2008.

[7] Schmidt M.: Moderne Fahrwerksrahmen-Fertigung in Graz. Glasers Annalen Nr. 125 0.3.2001.

[8] Sobaś M.: Tendencje rozwojowe $w$ układach biego wych przystosowanych do wysokich Prędkości. Materiaty konferencyjne.. XVIII Konferencja Pojazdów Szynowych. Katowice-Ustroń 17-19.09.2008.

[9] Wittenbeck L., Sobaś M.: Analiza modalna bezprzedziałowego wagonu osobowego. XVIII Konferencja Pojazdów Szynowych. Materiaty konferencyjne Politechniki Ślqskiej. Katowice-Ustroń 17-19.09.2008

[10] Zacher M.: Erfahrungen über Zusammenwirken von Fahrzeug und Fahrweg im Hochgeschwindigkeitsverkehr bei der Deutschen Bahn AG. Glasers Annalen 132, 6-7. 2008.

[11] Karta UIC 410: Skład i określenie ładunku oraz hamowania pociagów pasażerskich. 6-te wydanie $z$ sierpnia 2006.

[12] Karta UIC 505-1: Pojazdy kolejowe. Skrajnia pojazdów. 10-te wydanie z maja 2006

[13] Karta UIC 507: Wagony towarowe. Warunki, którym powinny odpowiadać wagony towarowe w komunikacji promowej. 1-sze wydanie, nowy nakład z 1.07.1997, ze zmiana $z$ 1.07.1997.

[14] Karta UIC 508-2: Urzqdzenia do czyszczenia i parkowania $w$ stanie gotowości do pracy dla pojazdów transportu pasażerskiego. 1-sze wydanie z 1.01.1994.

[15] Karta UIC 510-2:Pojazdy doczepne. Warunki do stosowania kół o różnych średnicach $w$ układach biegowych różnego typu. 4-te wydanie z 04. 2004.

[16] Karta UIC 515-0: Wagony pasażerskie. Wózki-Układy biegowe. 2-gie wydanie, kwiecień 2001.

[17] Karta UIC 515-1: Pojazdy dla transportu pasazerskiego. Wózki toczne. Układy biegowe. Ustalenia ogólne dla zespołów konstrukcyjnych wózków. 2-gie wydanie 03.2003.

[18] Karta UIC 515-3: Pojazdy kolejowe. Wózki-układy biegowe. Metoda obliczania osi zestawów kołowych. Wydanie 1-sze z 1.07.1994.

[19] Karta UIC 515-4: Pojazdy kolejowe dla transportu pasażerów. Wózki toczne -układy biegowe. Badania wytrzymałościowe ram wózków. 1-sze wydanie $z$ 1.01.1993.

[21] Karta UIC 515-5: Pojazdy trakcyjne i wagony. Wózki - układy biegowe. Badania maźnic zestawów kołowych. 1-sze wydanie z 1.07.1994. 
[22] Karta UIC 518: Badania i homologacja pojazdów szynowych z punktu widzenia właściwości dynamicznych, bezpieczeństwa jazdy, obciażenia toru i parametrów biegowych. 3-cie wydanie, październik 2005.

[23] Karta UIC 533: Uziemienie ochronne części metalowych pociagu. 2-gie wydanie z 1.01.1977.

[24] Karta UIC 543: Hamulec. Przepisy na wyposażenie wagonów. 12-te wydanie, czerwiec 2003

[25] Karta UIC 544-1: Hamulec. Hamowność. 4-te wydanie $z$ maja 2004.

[26] Karta UIC 541-05: Hamulec. Przepisy dotyczace budowy różnych części hamulca. Urzqdzenia antypoślizgowe. 2-gie wydanie, sierpień 2005.

[27] Karta UIC 546: Hamulec. Hamulec dużej mocy dla pociagów pasażerskich. 5-te wydanie z 1.01.1967.

[28] Karta UIC 552: Zasilanie pociagów w energię elektryczna. Ujednolicone charakterystyki techniczne szyny zbiorczej. 10-te wydanie z czerwca 2005.

[29] Karta UIC 567-1: Zunifikowane wagony pasażerskie typów X i Y dopuszczone do ruchu międzynarodowego. Charakterystyki. 4-te wydanie z 1.01.1978, 7-dma zmiana z 1.01.1994.

[30] Karta UIC 660:Przepisy dotyczqce zapewnienia kompatybilności technicznej dla pociagów do stosowania dużych prędkości. 2-gie wydanie, sierpień 2002.

[31] Karty UIC 814: Warunki techniczne dotyczqce homologacji oraz dostawy smarów przeznaczonych do smarowania maźnic tocznych pojazdów szynowych. 2-gie wydanie z 1.07.1978.
[32] Karta UIC 822: Warunki techniczne dostawy sprężyn śrubowych naciskowych formowanych na goraco lub zimno dla pojazdów trakcyjnych $i$ wagonów. 5-te wydanie z listopada 2003.

[33] PN-EN 12082:2000: Kolejnictwo- Maźnice- Badania eksploatacyjne

[34] PN-EN 13103:2003: Zestawy kołowe i wózki. Osie zestawów kołowych tocznych. Zasady konstrukcji.

[35] PN-EN 13260:2006: Kolejnictwo. Zestawy kolowe $i$ wózki. Wymagania dotyczace wyrobu

[36] PN-EN 13261:2004: Kolejnictwo- Zestawy kołowe $i$ wózki. Osie. Wymagania dotyczace wyrobu

[37] PN-EN 13262: 2005: Kolejnictwo. Zestawy kołowe $i$ wózki. Koła. Wymagania dotyczqce wyrobu.

[38] PN-EN 13298:2003: Kolejnictwo. Elementy zawieszenia. Stalowe sprężyny śrubowe zawieszenia.

[39] PN-EN 13749:2005: Kolejnictwo-Zestawy kołowe $i$ wózki-Metody określania wymagań konstrukcyjnych dla ram wózków.

[40] PN-EN 14363:2005: Kolejnictwo-Badania własności dynamicznych przed dopuszczeniem pojazdów szynowych. Badania własności biegowych i próby stacjonarne.

[41] Raport ORE/ERRI B176/DT278: Wplyw przemieszczenia poprzecznego belki bujakowej na profile pojazdów( ang.,, influence of lateral swing bolster play of vehicle profiles") Utrecht 04.1983.

[42] http: //www. khi.co.jp.

[43] http: //www. bombardier.com.

[44] http://www. transtec-vetschau.de 